\title{
Research Review The Role of Steroid Hormones in the NF1 Phenotype: Focus on Pregnancy
}

\author{
Therese M. Roth, ${ }^{1}$ Elizabeth M. Petty, ${ }^{2,3}$ and Kate F. Barald ${ }^{1,4 *}$ \\ ${ }^{1}$ Department of Cell and Developmental Biology, University of Michigan Medical School, Ann Arbor, Michigan \\ ${ }^{2}$ Department of Internal Medicine, University of Michigan Medical School, Ann Arbor, Michigan \\ ${ }^{3}$ Department of Human Genetics, University of Michigan Medical School, Ann Arbor, Michigan \\ ${ }^{4}$ Department of Biomedical Engineering, College of Engineering, University of Michigan Medical School, Ann Arbor, Michigan
}

Received 25 September 2007; Accepted 5 February 2008

\begin{abstract}
The Neurofibromatosis Type 1 (NF1) gene functions as a tumor suppressor gene. Loss of its protein, neurofibromin, in the autosomal dominant disorder NF1 is associated with peripheral nervous system tumors, particularly neurofibromas, benign lesions in which the major cell type is the Schwann Cell (SC). Benign and malignant human tumors found in NF1 patients are heterogeneous with respect to their cellular composition. The number and size of neurofibromas in NF1 patients has been shown to increase during pregnancy, with, in some cases, post-partum regression,
\end{abstract}

which suggests hormonal involvement in this increase. However, in this review, we consider evidence from the literature that both direct hormonal influence on tumor growth and on angiogenesis may contribute to these effects. (c) 2008 Wiley-Liss, Inc.

Key words: neurofibromatosis type 1; NF1; pregnancy; steroid hormones; steroid hormone receptors

How to cite this article: Roth TM, Petty EM, Barald KF. 2008. The role of steroid hormones in the NF1 phenotype: Focus on pregnancy. Am J Med Genet Part A 146A:1624-1633.

\section{NEUROFIBROMATOSIS TYPE I (NF1) AND TUMOR FORMATION}

The tumor suppressor gene, NF1, which encodes the neurofibromin protein, is responsible for one of the most common autosomal dominant disorders, neurofibromatosis type 1 (NF1), affecting 1/3,000 to $1 / 3,500$ individuals worldwide [Friedman et al., 1999]. Mutations in NF1 are responsible for widely varying phenotypes, including benign cutaneous tumors and numerous benign tumors of the peripheral nervous system such as neurofibromas, plexiform neurofibromas and optic nerve pathway gliomas [Viskochil et al., 1993; Gutmann et al., 1994; Blum and Kambich, 1997; Feldkamp et al., 1998; Packer et al., 2002; Zhu et al., 2002].

Neurofibromas are among the most commonly found and potentially debilitating manifestations of NF1. These benign growths, comprised mostly of Schwann cells (SC), but with substantive numbers of fibroblasts, mast cells, perineurial cells and vascular endothelial cells, arise on nerves that range in size from extremely small terminal branches to the spinal nerve roots. It is generally thought that SCs are the primary cells involved in the formation of neuro- fibromas, although the presence of two SC types, with and without loss of heterozygosity (LOH), suggests that LOH may not be the primary event triggering neurofibroma formation. Other cell types with NF1 loss may also be involved in neurofibroma formation. A major unanswered question is whether a decrease in neurofibromin as a result of haploinsufficiency is sufficient to induce neurofibroma formation, or whether other mutations, at the NF1 locus or other loci (e.g., P53, retinoblastoma), or environmental conditions including trauma, altered blood supply, and the elevated levels of specific hormones seen at puberty and during pregnancy, are

Grant sponsor: National Science Foundation Graduate Research Fellowship; Grant number: \#2004016780; Grant sponsor: NIH; Grant number: RO1 NS17262; Grant sponsor: Congressionally Mandated AMRMC Program; Grant number: NF990027.

*Correspondence to: Kate F. Barald, Ph.D., Department of Cell and Developmental Biology, University of Michigan Medical School, 3053 BSRB, 109 Zina Pitcher Place, Ann Arbor, MI 48109-2200.

E-mail: kfbarald@umich.edu

DOI 10.1002/ajmg.a.32301 
necessary triggers [Horyn et al., 1988; Zhu et al., 2002; Parada et al., 2005].

Individuals with NF1 cite neurofibromas as the single most significant burden of their disorder because of their disfiguring effects and associated physical and social discomfort [Wolkenstein et al., 2001; Page et al., 2006]. These tumors are rarely present at birth, but are found in $48 \%$ of 10 -year-old (notably, precocious puberty is a common feature of NF1) [Virdis et al., 2003], 84\% of 20-year-old, and virtually all NF1 patients over the age of 40. It has been reported [Karvonen et al., 2000] that many tiny neurofibromas have been found in the normallooking skin of NF1 patients, indicating a more widespread occurrence than was previously understood. Large neurofibromas can also arise from multiple nerves within plexuses, termed plexiform neurofibromas [Packer et al., 2002].

Plexiform neurofibromas, generally first arising in early childhood, are often relatively stable for a number of years, but are capable of aggressive growth, particularly as puberty approaches or during pregnancy. Diffuse plexiform neurofibromas are frequently associated with significant morbidity and even mortality. The presence of benign plexiform neurofibroma elements in soft tumors is commonly used by pathologists to make a diagnosis of malignant peripheral nerve sheath tumor (MPNST) in a soft tissue tumor. There are enough histopathological dissimilarities among discrete, nodular, and diffuse plexiform neurofibromas to suggest that different mechanisms exist for the formation of these different types of neurofibromas [Palmer et al., 2004].

\section{NF1 IN A CHANGING HORMONAL MILIEU: PREGNANCY}

The incidence of pregnancy among NF1 patients is relatively low and is inversely correlated with the severity of the disease, from about $1 / 5,000$ to about $1 / 18,000$ obstetrical patients has NF1, compared with the $1 / 3,000$ to $1 / 3,500$ overall NF1 incidence in live births [Blickstein et al., 1988; Weissman et al., 1993]. Obstetrical complications are important considerations for NF1-affected women of childbearing age, particularly in certain societal and third-world countries [Blum and Kambich, 1997]. Many have speculated that the number and size of the neurofibromas may increase in response to hormonal stimuli as commonly described by women during pregnancy [Posma et al., 2003], but a direct correlation of neurofibroma growth and hormonal stimulation remains to be elucidated.

Blickstein et al. [1988] and Blum and Kambich [1997] speculate that women with very mild cases of NF1 are frequently not diagnosed and their disorder either does not complicate pregnancy or, if symptoms worsen during the pregnancy, NF1 is then diagnosed. They further comment that women with severe clinical manifestations of NF1 rarely elect to bear children except in underdeveloped countries. There has been a reported increase in the number and size of cutaneous and plexiform neurofibromas with pregnancy going back over 100 years [Brickner, 1906; Dugoff and Sujansky, 1996; Blum and Kambich, 1997; Isikoglu et al., 2002; Posma et al., 2003]. There have also been reports that pregnant NF1 patients with giant "royal" tumors are more affected than patients with only nodular tumors, with possible reciprocal effects between NF1 and pregnancy [Blickstein et al., 1988]. The earliest obstetrical description of NF1, termed "fibroma molluscum gravidarum" was in 1906, by Brickner, while the adverse association between NF1 and pregnancy was first recognized by Hirst in 1911 [Brickner, 1906; Blickstein et al., 1988].

Only two studies of NF1 patients during pregnancy involve relatively large numbers of patients [Weissman et al., 1993; Dugoff and Sujansky, 1996]. These writers cite studies that suggest that NF1 patients have low marriage rates due to cosmetic disfigurement or may voluntarily choose to remain childless [Blickstein et al., 1988; Blum and Kambich, 1997]. The Dugoff and Sujansky study [Dugoff and Sujansky, 1996] reported on 105 women and 180 pregnancies: 60\% of patients reported growth of new neurofibromas; $52 \%$ experienced enlargement of existing neurofibromas, sometimes with a decrease in size of nodules after delivery. However, multiparous women who had NF1 experienced new growth of neurofibromas only in some pregnancies [Dugoff and Sujansky, 1996]. This observation is possibly due to mild cases remaining undiagnosed or severe cases more subject to report. The Weissman report [Weissman et al., 1993] was based on 34 pregnancies in nine NF1 patients; fertility did not seem to be impaired in women with NF1. However, this study found a higher than expected rate of first trimester spontaneous abortions (20.7\%), still births $(8.7 \%)$ and intrauterine growth retardation (13.0\%), which were not seen or possibly not reported in the Colorado study [Dugoff and Sujansky, 1996]. Additional studies have also reported growth retardation of the fetus in patients with NF1 [Belton et al., 1984; Blickstein and Lancet, 1987; Blum and Kambich, 1997].

Malignant degeneration of neurofibromas during pregnancy has also been reported [Ginsburg et al., 1981; Baker et al., 1989; Puls and Chandler, 1991; Posma et al., 2003], as well as maternal death from an intracranial hemorrhage resulting from a glioblastoma that recurred during pregnancy [Hadi, 1995]. A second pregnancy resulted in the overgrowth of a peripheral nerve sheath tumor that had initially arisen during a first pregnancy, which proved fatal to the patient [Posma et al., 2003]. Another case report found that a patient with initially mild disease symptoms died of the results of multiple malignancies, which the physician believed arose and became worse during and after pregnancy 
and delivery [Heffner 1969]. A combination of CNS tumor enlargement, new tumor appearance, hydrocephalus and hypertension in a pregnant patient with NF1 [Boiten et al., 1987] has also been reported.

In patients with NF1, pregnancy can cause severe hypertension and/or blood vessel weakness. An increased risk of hypertension has been recognized in all adults with NF1, but severe hypertension has been specifically noted in pregnant patients with NF1 [Wiznitzer et al., 1986; Bertrand et al., 1992; Hagymasy et al., 1998] including some earlier studies of patients whose pregnancies had to be terminated because of life-threatening conditions [Edwards et al., 1983]. At least one case was found in which the undiagnosed NF1 led to fatal complications under anesthesia [Humble, 1967]. There have also been reports in the literature of blood vessel rupture during pregnancy in NF1 patients, including a report of a patient with fatal renal artery rupture [Tapp and Hickling, 1969] and another NF1 patient whose arm was amputated after brachial artery rupture [Tidwell and Copas, 1998]. However, at least one report [Jarvis and Crompton, 1978] of a study of hypertension in 10 pregnant patients with NF1 in the course of 27 pregnancies found only two cases of preeclampsia, a still birth and four spontaneous abortions but the majority of pregnancies reported no evidence of hypertension; the number of hypertensive NF1 patients was also reportedly low in one study [Weissman et al., 1993], and no excessive hypertension was reported in the [Dugoff and Sujansky, 1996] study. No record was made of the patients' lesions, however, or whether they were affected by the pregnancies. Another study that attempted to relate hypertension to the number of neurofibromas found that development of hypertension and poor outcome in NF1 pregnancies is directly proportional to the number of lesions found in the patient [Sharma et al., 1991].

Prospective studies, such as those cited above, involved patients with relatively mild forms of the disorder whose pregnancies were obstetrically uneventful, even if there are reported increases in size and number of their neurofibromas [Dugoff and Sujansky, 1996]. In contrast, a large number of retrospective case studies by obstetricians and gynecologists tend to involve only a few women [Ansari and Nagamani, 1976] or even single patients [Ribella, 1975] and report severe, and therefore particularly notable, effects.

Essentially all of these studies, both large and small, are descriptive, providing no significant insight to the pathogenesis of disease progression. None of these reports presents a functional study of the mechanism of new lesion growth or the enlargement of preexisting lesions during pregnancy. One study done on both male and non-pregnant female neurofibroma tumors found $75 \%$ expressed progesterone receptor $(\mathrm{PR})$, while 5\% expressed estrogen receptor
(ER) [McLaughlin and Jacks, 2003]. Both male and female tumor cells were tested, but whether sex of the patient affected the levels of PR and ER expression was not reported. A recent report by Fishbein et al. [2007] investigated the potential role of pregnancy steroid hormone action on the growth, proliferation and tumorigenicity of cells that do or do not express the NF1 gene or its protein product, neurofibromin. It is the first published study of RNA levels of steroid hormone receptors in primary NF1 tumor cells, Schwann Cell (SC)-enriched NF1 tumor cells and normal SC, along with an analysis of proliferation and apoptosis. This study found heterogeneity among the cell types, regardless of tumor origin or gender, suggesting the importance of the individual tumor's microenvironment [Fishbein et al., 2007]. We have recently published an additional study [Roth et al., 2008], in which a mouse embryonic stem cells (mESCs) with varying levels of neurofibromin were differentiated into Schwannlike cells and proliferation in response to hormones was compared to that in human NF1 cell lines derived from malignant or benign tumors. Although estrogen and androgen receptors were not expressed or expressed at very low levels in the $N f 1^{+/}$cells, and were expressed at low levels in $N f 1^{+/-}$cells, robust levels of these hormone receptors were expressed in all the $N \mathrm{N1}^{-/-}$cells and the tumor cell lines. An E2 metabolite, 2Methoxyestradiol was found to be cytotoxic to the $\mathrm{NF}^{-/-}$malignant tumor cell line, suggesting a potential new therapeutic avenue for treatment of NF1 hormone responsive tumors.

We put forward the hypothesis that hormones, particularly those that increase during pregnancy acting on cells that lack neurofibromin, are responsible for the observed increase in both size and numbers of cutaneous and plexiform neurofibromas in pregnant patients with NF1.

\section{THE HORMONAL MILIEU DURING PREGNANCY}

Steroid hormones, such as 17 $\beta$-estradiol (E2), progesterone (P4) and testosterone $(\mathrm{T})$, are derived from cholesterol precursors, with P4 synthesized first, followed by $\mathrm{T}$, which is a precursor for $\mathrm{E} 2$, which is converted to E2 through the aromatase enzyme [Gao et al., 2005] (Fig. 1). In non-pregnant women, steroid hormones are primarily synthesized by the ovary. Concentrations of these steroid hormones are upregulated during pregnancy [Witorsch 2002; Fernandez-Valdivia et al., 2005; Okada et al., 2005; Rodriguez-Cuenca et al., 2006; Gardner et al., 2007]. In early pregnancy, the corpus luteum produces these hormones, but the placenta is the dominant source of steroid hormones by the seventh gestational week [Gardner et al., 2007].

All placental-produced steroids are derived from maternal or fetal cholesterol precursor steroids [Gardner et al., 2007]. Progesterone (P4) uses maternal 


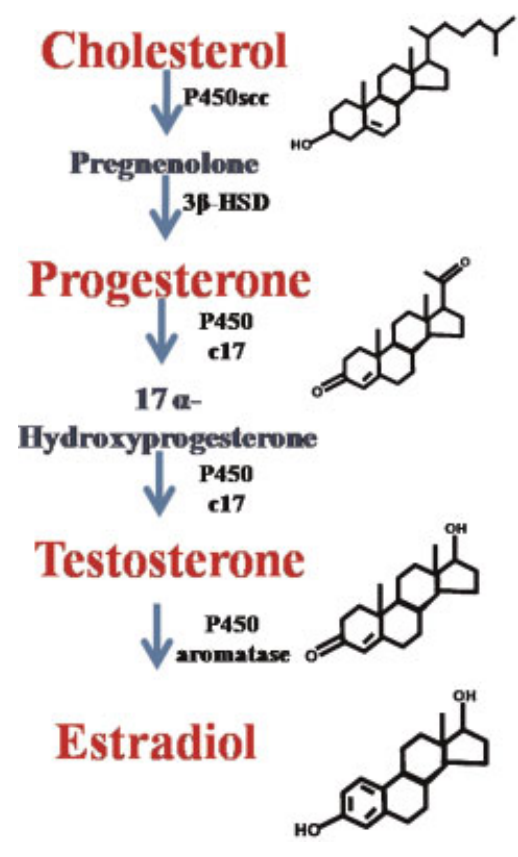

FIG. 1. Steroid hormone synthesis. The steroid hormones progesterone testosterone, and $17 \beta$-estradiol are upregulated during pregnancy. All of these steroid hormones are originally synthesized from cholesterol and converted to the respective hormones through enzymatic action. Steroid hormones are ligands for classical steroid receptors that activate downstream genes, promoting proliferation and differentiation. Progesterone is the ligand for the progesterone receptor, estrogen for the estrogen receptor, and testosterone for the androgen receptor, although they can also cross-react with lower affinity. There are also other, non-classical steroid hormone pathways that allow for quick response to hormonal stimulation through secondary messengers and small G-proteins. [Color Fig. can be viewed in the online issue, which is available at www.interscience.wiley.com.]

cholesterol as a substrate, while $17 \beta$-estradiol (E2) depends on both maternal and fetal sources. Most E2 is derived from testosterone (T) precursors, which are also increased during normal pregnancy. Plasma concentrations of $\mathrm{E} 2, \mathrm{P} 4$ and $\mathrm{T}$ hormones increase progressively throughout pregnancy (Table I) [Gardner et al., 2007]. After birth, steroid hormone levels decline rapidly, falling to pre-pregnancy follicular stage levels within 1-3 days [Gardner et al., 2007].

E2 has been shown to be involved in cell proliferation, and is a ligand for the estrogen receptor (ER) [Revankar et al., 2005; Boonyaratanakornkit and Edwards, 2007]. P4 modifies E2 and is involved in both proliferation and differentiation [FernandezValdivia et al., 2005]; P4 is the ligand for the progesterone receptor (PR) [Fernandez-Valdivia et al., 2005; Boonyaratanakornkit and Edwards, 2007]. The PR is regulated by E2 by transactivation through the ER [Fernandez-Valdivia et al., 2005; Okada et al., 2005]. Steroids can cross-react and bind to receptors other than their native receptor, because of the similarity of the receptor conformation, even though the actual sequence identity may be low [Gao et al., 2005]. Testosterone is the primary circulating androgen, even in women, and is the ligand for the androgen receptor (AR), although it can also crossreact with both the ER and PR at low affinity [Gao et al., 2005; Boonyaratanakornkit and Edwards, 2007]. Steroid receptors (ER, PR, and AR) belong to the nuclear receptor family of transcription factors, which are activated when their ligand (E2, P4 or T) binds to the nuclear-envelope-anchored receptor and the complex subsequently enters the nucleus to bind to hormone response elements (HRE) in gene promoter regions, thereby activating transcription of downstream effector genes [Fernandez-Valdivia et al., 2005; Boonyaratanakornkit and Edwards 2007; Gavrilova-Jordan and Price 2007] (Fig. 2). Tumor cells which express both ER and PR have a better prognosis because they are more likely to respond to hormone treatment [Jacobsen et al., 2003], although tumors that express only ER or PR, but not both, have been reported to have a poorer outcome [Jacobsen et al., 2005].

However, steroid hormone action is not mediated exclusively through classical pathways [McEwen and Alves, 1999; Ho and Liao, 2002; Zhang et al., 2004; Chen et al., 2005; Gao et al., 2005; Jacobsen et al., 2005; Revankar et al., 2005; Sonneveld et al., 2006; Gavrilova-Jordan and Price, 2007]. There have been reports of steroid hormones (P4, E2, T) influencing cells independently of their classical receptors (PR, ER, AR) [McEwen and Alves, 1999; Ho and Liao, 2002; Zhang et al., 2004; Chen et al., 2005; Gao et al., 2005; Jacobsen et al., 2005; Revankar et al., 2005; Sonneveld et al., 2006; Gavrilova-Jordan and Price, 2007]. Conversely, the receptors have also been shown to exert their influence without hormones [Chen et al., 2005; Jacobsen et al., 2005; Sonneveld et al., 2006]. ER expression has been seen outside the nucleus [McEwen and Alves, 1999; Ho and Liao, 2002; Zhang et al., 2004; Revankar et al., 2005]. E2 has also been shown to modulate secondary messengers, such as $\mathrm{Ca}^{++}$and $\mathrm{NO}$,

TABLE I. Steroid Hormone Expression Changes During Pregnancy

\begin{tabular}{|c|c|c|c|}
\hline Steroid hormone & Expression pattern & $\begin{array}{c}\text { Average pre-conception concentra- } \\
\text { tion }\end{array}$ & $\begin{array}{c}\text { Average peak concentration at } \\
\text { term }\end{array}$ \\
\hline $17 \beta$-Estradiol (E2) & Increases to term $^{\mathrm{a}}$ & $1.2-2.6 \mathrm{nmol} / \mathrm{L}^{\mathrm{a}}(0.033-0.070 \mu \mathrm{g} / \mathrm{dl})^{\mathrm{a}}$ & $42-52 \mathrm{nmol} / \mathrm{L}^{\mathrm{a}}(12-15 \mathrm{ng} / \mathrm{ml})^{\mathrm{a}}$ \\
\hline Progesterone (P4) & Increases to term ${ }^{\mathrm{a}}$ & $36 \mathrm{nmol} / \mathrm{L}^{\mathrm{a}}(1.13 \mu \mathrm{g} / \mathrm{dl})^{\mathrm{a}}$ & $552 \mathrm{nmol} / \mathrm{L}^{\mathrm{a}}(190 \mathrm{ng} / \mathrm{ml})^{\mathrm{a}}$ \\
\hline Testosterone $(\mathrm{T})$ & Increases to term ${ }^{\mathrm{a}}$ & $1.3 \mathrm{nmol} / \mathrm{L}^{\mathrm{a}}(0.038 \mu \mathrm{g} / \mathrm{dl})^{\mathrm{a}}$ & $6.9 \mathrm{nmol} / \mathrm{L}^{\mathrm{a}}(2,000 \mathrm{pg} / \mathrm{ml})^{\mathrm{a}}$ \\
\hline
\end{tabular}

Expression of the steroid hormones $17 \beta$-estradiol (E2), progesterone (P4) and testosterone (T) increase progressively throughout pregnancy. Hormone expression returns to pre-conception levels within days of giving birth

${ }^{a}$ Gardner et al. [2007] 


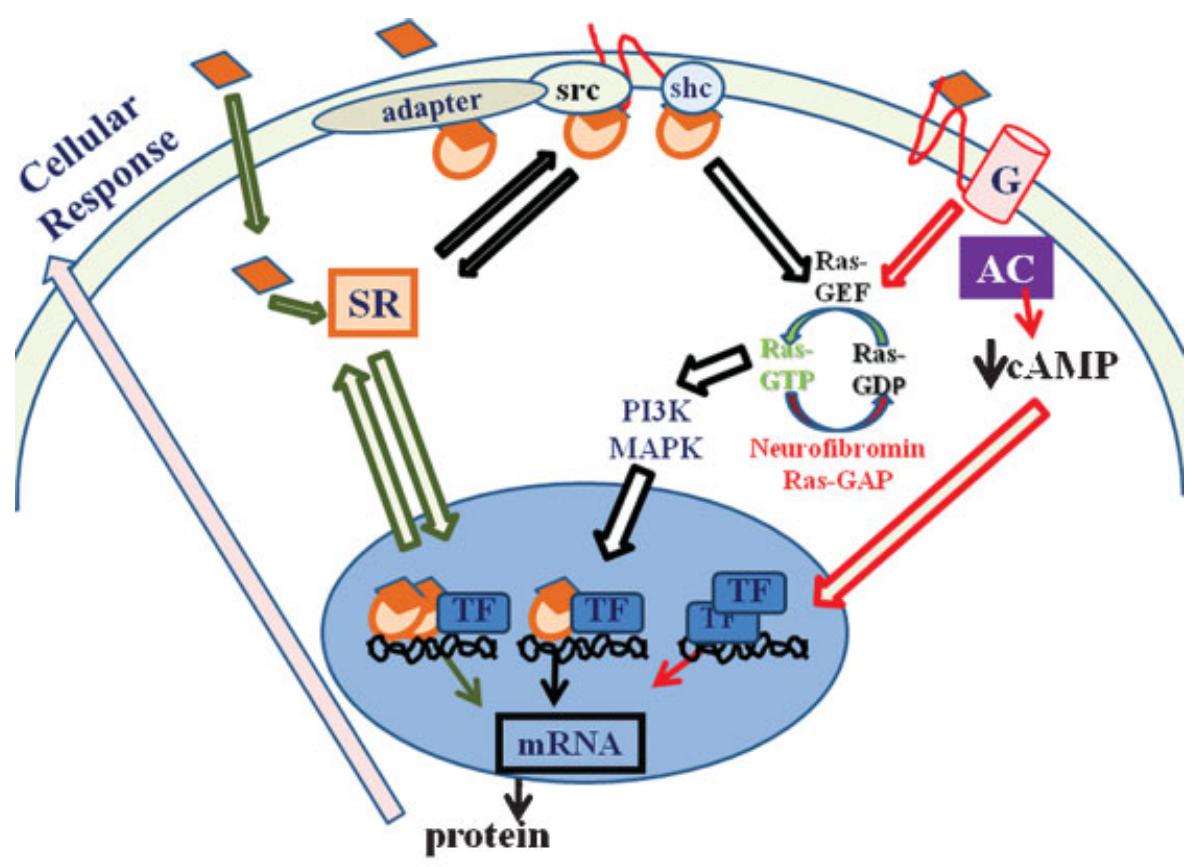

\section{Classical}

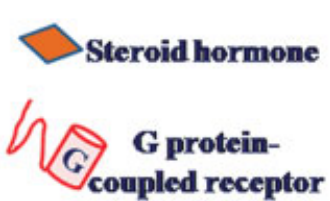

Non-classical

\section{Independent}
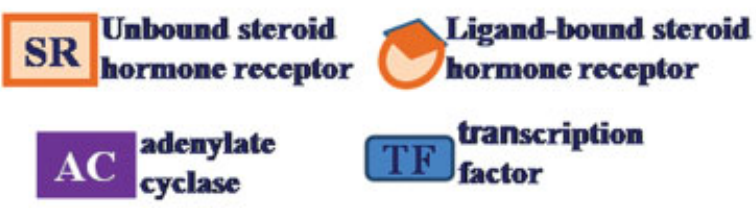

FIG. 2. Steroid hormone pathways. In the classical pathway (left side), steroid hormones bind to classical receptors in the cell, where they induce conformational changes. The steroid/receptor complex then translocates to the nucleus where it dimerizes, binds to genes via transcription factors and hormone response elements and activates transcription, leading to protein production and cellular responses. In the non-classical pathway (middle), membrane-bound or cytoplasmic steroid receptors associate with signaling molecules. Neurofibromin's most well-characterized function is as a Ras-GAP tumor suppressor. Following ligand/receptor binding and the resulting signal, neurofibromin accelerates the hydrolyzation of active Ras-GTP to inactive Ras-GDP, thus turning off multiple downstream signaling cascades, such as PI3K and MAPK. When the NF1 gene is missing or mutated, neurofibromin is not available to shut down these pathways, leaving them constitutively active. This can result in uncontrolled cell growth and formation of peripheral nerve tumors called neurofibromas. In the steroid receptor-independent pathway (right side), novel G protein-coupled receptors that are unrelated to classical nuclear steroid receptors, mediate rapid, non-genomic signaling cascades through adenylate cyclase inhibition, cAMP production and MAPK activation. Other transcription factors are also involved in these pathways. [Color Fig. can be viewed in the online issue, which is available at www.interscience. wiley.com.]

and activate the PI3K/Akt and MAPK pathways [Ho and Liao, 2002; Boonyaratanakornkit and Edwards, 2007; Gavrilova-Jordan and Price, 2007]. These effects are not inhibited by ER inhibitors, suggesting they are not mediated through the classical receptors [Ho and Liao, 2002] (Fig. 2).

The most potent hormone effector in pregnancy is estrogen in the form of $17 \beta$-estradiol (E2). It promotes the proliferation of endometrial cells in the uterus, and is essential for maintaining pregnancy. It is initially produced by the corpus luteum and later by the placenta [Gardner et al., 2007]. Additional estradiol species are also produced, including

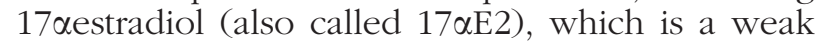
estrogen, and induces some estrogen responsive genes, including vascular endothelial growth factor (VEGF) that promotes angiogenesis-new blood vessel formation. However, its action in rat pituitary tumor cells is independent of the estrogen receptors
(ER), and instead acts through the PI3Kinase-AKT signaling pathway. There is evidence that this is also the pathway through which neurofibromin acts [Klesse and Parada 1998].

E2 also has proliferative effects on estrogenresponsive tumor cells. It has been demonstrated [Ahmad et al., 1999] that in the MCF-7 breast carcinoma cell line, E2 upregulates AKT activity and increases cell proliferation. Both the anti-estrogen ICI 182,780 (ICI) and wortmannin (the PI3K inhibitor) block this effect [Ahmad et al., 1999]. In addition, it has been demonstrated [Wilson et al., 2002] that estradiol treatment reduced the number of neuronal cells undergoing apoptotic cell death. These authors examined the level of activation of Akt kinase that mediates the anti-apoptotic signals. Explants treated with estradiol had elevated levels of pAkt and treatment with ICI prevented the effect of estradiol, suggesting that estradiol prevents injury-induced 
apoptosis in neurons and that Akt activation is probably responsible for this effect [Wilson et al., 2002]. Although the evidence at this time is only circumstantial, there is a good possibility that the two pathways, the NF1-dependent pathway and the estrogen-dependent pathway both interact through effects on PI3 Kinase.

Progesterone, which is also critical for maintaining pregnancy, is also increasingly produced during the course of pregnancy [Gardner et al., 2007]. P4 can be involved in cell differentiation and modulation of E2 proliferative effects. E2 and P4 can have complementary functions, with P4 inhibiting the ER [Jacobsen et al., 2003; Gardner et al., 2007]. An increase in E2:P4 ratio may be a factor in initiating labor [Gardner et al., 2007]. P4 and E2 can be used in combination to stimulate tumor development by simulating pregnancy in mice with dormant mammary tumors [Gattelli et al., 2004]. The combination of E2 and P4 caused the tumor cells to break dormancy and begin proliferating.

There are two distinct forms of the estrogen receptor (ER), ER $\alpha$ and $E R \beta$, which are transcribed from different genes [Boonyaratanakornkit and Edwards, 2007]. Both subtypes bind estrogens as well as selective ER modifiers (SERMs) including the anti-cancer agent tamoxifen and a number of other anti-cancer ER inhibitors [Cummings, 2002; Boonyaratanakornkit and Edwards, 2007]. ER receptors are classically located in the nucleus although they can also be located in the nuclear or mitochondrial membrane [Gavrilova-Jordan and Price, 2007]. PR, as well as AR, have also been found on mitochondrial membranes, and are very similar/ identical to nuclear steroid receptors [GavrilovaJordan and Price, 2007].

Classical steroid receptors form dimers, interact with basal transcription factors and coactivators and bind to hormone response elements (HRE) in DNA, leading to the modulation of target gene transcription. The distribution of the ER and PR subtypes varies among tissues and among cells in a specific tissue, and their expression also varies during development [Van Den Bemd et al., 1999; Boonyaratanakornkit and Edwards, 2007].

ICI 182,780 at $10^{-7} \mathrm{M}$ is a pure antiestrogen that leads to the downregulation and subsequent loss of the estrogen receptors themselves [Wakeling et al., 1991; Van Den Bemd et al., 1999; Cicatiello et al., 2000]. It also has estrogen receptor antagonistic effects and inhibits estrogen binding to both the $\alpha$ and $\beta$ forms of the human estrogen receptor (ER) [Robertson et al., 2001; Garnier et al., 2003]. ICI has been shown to inhibit the growth of breast cancer cells and cell lines [Robertson et al., 2001]. It has also been shown to be effective against tamoxifenresistant breast cancer in post-menopausal women [Robertson et al., 2001]. ICI induces a conformational change in the ER and induces a ligand concentration- dependent increase in proteolytic degradation. ICI has anti-progestin effects in a human breast cancer cell line, blocking progesterone responsive genes such as vascular endothelial growth factor (VEGF), which is a potent angiogenic growth factor [Hyder and Stancel, 2002]. ICI blocked progestin-induced VEGF mRNA and protein synthesis [Hyder and Stancel, 2002], although it did not block binding of progestin to the PR or down-regulate the endogenous PR. Estrogen does not upregulate VEGF in these breast cancer cells. Therefore ICI could block angiogenesis in the breast cancer cell line through a mechanism unrelated to its ER inhibition and the authors suggest that either ICI binds to a site in the PR different from its ligand binding site and/or ICI binds to a co-activator or co-repressor or to yet another protein involved in the transcriptional complex associated with par responsive genes such as VEGF. ICI also effectively inhibits the ER in the hippocampus but not the frontal cortex of the brain [Mize et al., 2003]. Studies in both rodents and primates have shown that progestins can counteract the antiatherogenic effects of estrogens. ICI inhibits these effects demonstrating that the antiatherogenic effects of E2 are mediated through the ER and studies with ER knockout mice also demonstrate that ERs mediate these protective effects of estrogen on the vasculature [Karas, 2002].

2-Methoxyestradiol (2ME2) is a natural estrogen metabolite of E2 that has no estrogenic effects itself but has both antiangiogenic and antitumorigenic effects [Fotsis et al., 1994; Lin et al., 2001; Schumacher and Neuhaus, 2001; Carothers et al., 2002], including effects on osteosarcoma [Maran et al., 2002] and Ewing sarcoma [Djavaheri-Mergny et al., 2003]. Both microvasculature and large vessel endothelial cell proliferation are also blocked by 2ME2 [Fotsis et al., 1994]. Proliferation of many types of normal cells, including thyroid cells [Wang et al., 2000] and chondrocytes in the growth plate [Sibonga et al., 2002] are inhibited by 2ME2. However, 2ME2induced apoptosis is independent of the estrogen receptors $\alpha$ and $\beta$ [LaVallee et al., 2002]. Analogues of 2ME2 have been made and tested for their enhanced inhibitory abilities and one analogue, 14-Dehydro-2-ME-2, was 16-fold more potent than 2-ME2 against various tumor cell lines, including prostate cancer cell lines [Tinley et al., 2003]. An important study of $2 \mathrm{ME} 2$ demonstrated that $2 \mathrm{ME} 2$, which has only weak affinity for the ER, not only has antiproliferative activity but also alters tubulin dynamics [Brueggemeier et al., 2001]. A variant of this metabolite, 2-methoxymethylestradiol, was more effective than the native metabolite in producing cytotoxicity and altering tubulin dynamics in intact cells [Brueggemeier et al., 2001].

During pregnancy, 2ME2 may put a growth check on estrogen-stimulated cell growth. We hypothesize that (1) levels of both estrogens and 2ME2 may be 
different in women with NF1 from those in women without NF1 and (2) 2ME2 levels might be lower in NF1 patients. If 2ME2 levels are lower in individuals with NF1, it may be unable to compensate for estrogen levels that promote the growth of neurofibromas and might also be involved in the conversion of benign to malignant tumors that has also been reported in some pregnant NF1 patients [Posma et al., 2003]. However, there are no studies in the literature examining the levels of hormones or hormone metabolites in the pregnant women with NF1. Furthermore, most of the studies published to date about women with NF1 are descriptive. There are no studies of the mechanism by which any of these hormones or metabolites act on cells that do or do not make neurofibromin.

\section{POSSIBLE ROLE OF STEROIDS IN HYPERTENSION AND VASCULAR STRUCTURE ALTERATIONS SEEN IN PREGNANT PATIENTS WITH NF1}

Vascular endothelial growth factor (VEGF) is a major inducer of tumor angiogenesis [Ruohola et al., 1999]. It is expressed in endothelial cells, and its expression in cancer cells, such as breast cancer cells, indicates a poor prognosis for tumor progression. Neurofibromas tend to be highly vascular [Thomas and De Vries, 2007]. 17ßestradiol (E2) upregulates VEGF mRNA in many cancer cells [Ruohola et al., 1999], leading to subsequent angiogenesis. ICI inhibits the E2-mediated upregulation indicating that it is probably an ER-dependent mechanism [Ruohola et al., 1999]. In contrast, tamoxifen also upregulates VEGF mRNA on its own and has no inhibitory effect such as that of ICI [Ruohola et al., 1999].

E2 inhibits vascular smooth muscle cell proliferation whereas ICI causes proliferation of these cells [Lavigne et al., 1999]. It has also been reported that short-term exposure to pharmacological levels of $17 \alpha$ or $17 \beta$-estradiol (E2) produced relaxation in pig coronary artery in organ culture [Teoh et al., 1999]. However, physiological concentrations of estradiol also enhanced the endothelium-independent relaxation of pig coronary artery produced by other agents. This relaxation was not blocked either by tamoxifen or by ICI, suggesting that the effect is mediated through a different ER and that E2 may be responsible for acute effects on blood flow by a different mechanism than that involved in ER downregulation. Additional effects on the blood system include effects on the integrity of the endothelial cell lining of blood vessels that is affected by E2 [Cho et al., 1998]. Tight junctions between the endothelial cells are critically important for maintaining the integrity of the blood vasculature. E2 increases the cation specificity of the tight junctions. In addition, E2 also acts as an antioxidant at the genomic level. By improving the $\mathrm{NO} / \mathrm{O}_{2}{ }^{-}$balance; E2 keeps the expression of proatherosclerotic gene products low and regulated in endothelial cells [Wagner et al., 2001].

Extracellular $\mathrm{Ca}^{++}$is essential for maintaining occlusion of the paracellular space in endothelial cells by tight junctions [Cho et al., 1998]. If extracellular calcium is lowered, cells separate, weakening blood vessel walls, which eventually leads to rupture [Cho et al., 1998]. Estrogen modulates tight junctional resistance across the endothelial cells [Teoh et al., 1999]. Estrogen increases the tight junctional permeability to ions [Teoh et al., 1999]. A nuclear receptor, but probably not the ER, mediates the effect of estrogen on cation selectivity [Revankar et al., 2005].

\section{POSSIBLE HORMONAL INVOLVEMENT IN MALIGNANT TRANSFORMATION}

It has been postulated that hormones are involved in the progression of benign lesions (neurofibromas) to malignant peripheral nerve sheath tumors (MPNST) [Fishbein et al., 2007]. A recent study describes RNA levels of steroid hormone receptors, along with the effects of the steroid hormones progesterone (P4), estrogen (E2), or testosterone (T) on primary and SC-enriched human benign and malignant NF tumor cell lines and normal SC [Fishbein et al., 2007]. Fishbein et al. [2007] found a great deal of heterogeneity in estrogen receptor, progesterone receptor, and androgen receptor expression in normal SC and most NF1 tumor samples tested, with no clear division based on tumor type or gender. The greatest variation in hormone receptor levels occurred between primary tumor cells versus SC-enriched tumor cell cultures, suggesting that cell types other than the SC have steroid hormone receptors. There were also some statistically significant differences in proliferation and apoptosis in cells exposed to steroid hormones or their antagonists, but these differences were also heterogeneous. These data did not fit into a simplistic or global model to explain the functional role of hormonal pathways in the progression of NF1; however, they suggest that the surrounding cells unique to each tumor's microenvironment were important to tumorigenicity, and that classical steroid receptor effects may only apply to a subset of NF1 tumors, regardless of gender [Fishbein et al., 2007]. Our own studies of Schwann Cell-like (SC-like) differentiated mouse embryonic stem cells (mESC) that have been engineered to lack neurofibromin are consistent with this finding [Roth et al., 2007, 2008]. We reported that $N f 1^{-/-}$mESC, as well as NF1deficient mouse tissues and $N F 1^{-/-}$human tumor cells, expressed higher levels of classical steroid hormone receptors than cells and tissues with full expression of neurofibromin. The addition of hormones had a modest but significant direct effect on the classical pathway in the $N F 1^{-/-}$SC-like cells and 
on malignant $\mathrm{NF}^{-/-}$human tumor cell lines that we tested. A naturally occurring estrogen metabolite, 2ME2, induced apoptosis only in the malignant $N F 1^{-/-}$human tumor cells [Roth et al., 2008].

\section{POSTULATED INTERACTIONS OF NF1, ESTROGENS AND APOPTOSIS PATHWAYS}

We hypothesize that hormones influence NF1mediated apoptotic events through the phosphatidylinositol 3 kinase (PI3K) pathway, which has been implicated in NF1 signal transduction [Yao and Cooper, 1995; Klippel et al., 1996; Rodriguez-Viciana et al., 1996; Kulik et al., 1997; Parrizas and LeRoith, 1997; Stokoe et al., 1997; Crowder and Freeman, 1998; Klesse and Parada, 1998; Klesse et al., 1999]. A report also suggests that the PI3K cascade mediates the neuroprotective effects of estrogen on cortical neurons [Honda et al., 2000], making this hypothesis even more attractive to test.

Over the past decade, the NF1 community of researchers has gained significant insight into the genetic mechanisms underlying NF1. However, to date the hormonal pathways modulating NF1 phenotypes have not been well elucidated. Over the years patients with NF1 have reported a dramatic change in tumor number and size during puberty as well as pregnancy suggesting hormonal regulation of tumor growth. While the possibility that some cells in the tumors are hormone-responsive has always been viewed as quite plausible given our recognition of hormonal responsiveness of many tumor types, little scientific evidence has supported this clinical observation. Recently, new insights into the hormonal regulation of neurofibromas' growth have been reported as summarized above. Further studies into the molecular mechanisms delineating how hormonal stimulation regulates neurofibroma growth are necessary to provide a more accurate understanding of the natural history of the condition, and lead to the development of innovative tools for the management of patients who have NF1. Recognition by clinicians of the hormonal impact of NF1 is essential to provide care of patients. Ideally, further knowledge about the pathways and modifying facts of NF1 will be instrumental in the improving the prognostic and therapeutic management of the disease as well.

\section{ACKNOWLEDGMENTS}

This work was supported by a National Science Foundation Graduate Research Fellowship [\#2004016780] to TMR and grants from the NIH [RO1 NS17262] and Congressionally Mandated AMRMC Program [NF990027] to KFB. We are grateful for the Calvin Roach Memorial gift (to EMP) for the study of neurofibromatosis.

\section{REFERENCES}

Ahmad S, Singh N, Glazer RI. 1999. Role of AKT1 in 17betaestradiol- and insulin-like growth factor I (IGF-I)-dependent proliferation and prevention of apoptosis in MCF-7 breast carcinoma cells. Biochem Pharmacol 58:425-430.

Ansari AH, Nagamani M. 1976. Pregnancy and neurofibromatosis (von Recklinghausen's disease). Obstet Gynecol 47:25S-29S.

Baker VV, Hatch KD, Shingleton HM. 1989. Neurofibrosarcoma complicating pregnancy. Gynecol Oncol 34:237-239.

Belton SR, Ferguson JE II, Catanzarite VA. 1984. Neurofibromatosis and pregnancy: Report of a case complicated by intrauterine growth retardation and oligohydramnios. Am J Obstet Gynecol 149:468-469.

Bertrand C, Ville Y, Fernandez H. 1992. Hereditary hypertension in Recklinghausen's disease during pregnancy. A family. Presse Med 21:2142-2144.

Blickstein I, Lancet M. 1987. Neurofibromatosis and pregnancy. Harefuah 112:392-393.

Blickstein I, Lancet M, Shoham Z. 1988. The obstetric perspective of neurofibromatosis. Am J Obstet Gynecol 158:385-388.

Blum K, Kambich MP. 1997. Maternal genetic disease and pregnancy. Clin Perinatol 24:451-465.

Boiten J, Jansen EN, de Graaff R. 1987. Von Recklinghausen neurofibromatosis (VRNF) and pregnancy. A single case study. Clin Neurol Neurosurg 89:181-184.

Boonyaratanakornkit V, Edwards DP. 2007. Receptor mechanisms mediating non-genomic actions of sex steroids. Semin Reprod Med 25:139-153.

Brickner S. 1906. Fibroma molluscum gravidarum: A new clinical entity. Am J Obstet Gynecol 53:191-199.

Brueggemeier RW, Bhat AS, Lovely CJ, Coughenour HD, Joomprabutra S, Weitzel DH, Vandre DD, Yusuf F, Burak WE Jr. 2001. 2-Methoxymethylestradiol: A new 2-methoxy estrogen analog that exhibits antiproliferative activity and alters tubulin dynamics. J Steroid Biochem Mol Biol 78:145156.

Carothers AM, Hughes SA, Ortega D, Bertagnolli MM. 2002. 2-Methoxyestradiol induces p53-associated apoptosis of colorectal cancer cells. Cancer Lett 187:77-86.

Chen Y, Zajac JD, MacLean HE. 2005. Androgen regulation of satellite cell function. J Endocrinol 186:21-31.

Cho MM, Ziats NP, Abdul-Karim FW, Pal D, Goldfarb J, Utian WH, Gorodeski GI. 1998. Effects of estrogen on tight junctional resistance in cultured human umbilical vein endothelial cells. J Soc Gynecol Investig 5:260-270.

Cicatiello L, Addeo R, Altucci L, Belsito Petrizzi V, Boccia V, Cancemi M, Germano D, Pacilio C, Salzano S, Bresciani F, Weisz A. 2000. The antiestrogen ICI 182,780 inhibits proliferation of human breast cancer cells by interfering with multiple, sequential estrogen-regulated processes required for cell cycle completion. Mol Cell Endocrinol 165:199-209.

Crowder RJ, Freeman RS. 1998. Phosphatidylinositol 3-kinase and Akt protein kinase are necessary and sufficient for the survival of nerve growth factor-dependent sympathetic neurons. J Neurosci 18:2933-2943.

Cummings FJ. 2002. Evolving uses of hormonal agents for breast cancer therapy. Clin Ther 24:C3-C25.

Djavaheri-Mergny M, Wietzerbin J, Besancon F. 2003. 2Methoxyestradiol induces apoptosis in Ewing sarcoma cells through mitochondrial hydrogen peroxide production. Oncogene 22:2558-2567.

Dugoff L, Sujansky E. 1996. Neurofibromatosis Type 1 and pregnancy. Am J Med Genet 66:7-10.

Edwards JN, Fooks M, Davey DA. 1983. Neurofibromatosis and severe hypertension in pregnancy. Br J Obstet Gynaecol 90:528-531.

Feldkamp MM, Gutmann DH, Guha A. 1998. Neurofibromatosis type 1: Piecing the puzzle together. Can J Neurol Sci 25:181191.

Fernandez-Valdivia R, Mukherjee A, Mulac-Jericevic B, Conneely OM, Demayo FJ, Amato P, Lydon JP. 2005. Revealing 
Progesterone's Role in Uterine and Mammary Gland Biology: Insights from the Mouse. Semin Reprod Med 23:22-37.

Fishbein L, Zhang X, Fisher LB, Li H, Campbell-Thompson M, Yachnis A, Rubenstein A, Muir D, Wallace MR. 2007. In vitro studies of steroid hormones in neurofibromatosis 1 tumors and schwann cells. Mol Carcinog 46:512-523.

Fotsis T, Zhang Y, Pepper MS, Adlercreutz H, Montesano R, Nawroth PP, Schweigerer L. 1994. The endogenous oestrogen metabolite 2-methoxyoestradiol inhibits angiogenesis and suppresses tumour growth. Nature 368:237-239.

Friedman JM, Gutmann DH, MacCollin M, Riccardi VM. 1999. Neurofibromatosis: Phenotype, natural history, and pathogenesis. Baltimore, MD: Johns Hopkins University Press. $381 \mathrm{p}$.

Gao W, Bohl CE, Dalton JT. 2005. Chemistry and structural biology of androgen receptor. Chem Rev 105:3352-3370.

Gardner DG, Shoback DM, Greenspan FS. 2007. Greenspan's basic \& clinical endocrinology. McGraw-Hill's AccessMedicine 8th edition. New York: McGraw-Hill Medical.

Garnier M, Giamarchi C, Delrieu I, Rio MC, Chinestra P, Bayard F, Poirot M, Faye JC. 2003. Insulin and estrogen receptor ligand influence the FGF-2 activities in MCF-7 breast cancer cells. Biochem Pharmacol 65:629-636.

Gattelli A, Cirio MC, Quaglino A, Schere-Levy C, Martinez N, Binaghi M, Meiss RP, Castilla LH, Kordon EC. 2004 Progression of pregnancy-dependent mouse mammary tumors after long dormancy periods. Involvement of Wnt pathway activation. Cancer Res 64:5193-5199.

Gavrilova-Jordan LP, Price TM. 2007. Actions of steroids in mitochondria. Semin Reprod Med 25:154-164.

Ginsburg D, Hernendez E, Johnson J. 1981. Sarcoma complicating von Recklinghausen disease in pregnancy. Obstet Gynecol 58:385-387.

Gutmann DH, Cole JL, Collins FS. 1994. Modulation of neurofibromatosis type 1 gene expression during in vitro myoblast differentiation. J Neurosci Res 37:398-405.

Hadi HA. 1995. Clinical significance of neurofibromatosis in pregnancy. Am J Perinatol 12:459-461.

Hagymasy L, Toth M, Szucs N, Rigo J Jr. 1998. Neurofibromatosis type 1 with pregnancy-associated renovascular hypertension and the syndrome of hemolysis, elevated liver enzymes, and low platelets. Am J Obstet Gynecol 179:272-274.

Heffner RR Jr. 1969. Hydromyelia in Von Recklinghausen's disease with neurofibrosarcoma. Conn Med 33:311-313.

Ho KJ, Liao JK. 2002. Nonnuclear actions of estrogen. Arterioscler Thromb Vasc Biol 22:1952-1961.

Honda K, Sawada H, Kihara T, Urushitani M, Nakamizo T, Akaike A, Shimohama S. 2000. Phosphatidylinositol 3-kinase mediates neuroprotection by estrogen in cultured cortical neurons. J Neurosci Res 60:321-327.

Horyn G, Bourgeois-Dujols P, Palaric JC, Giraud JR. 1988 Recklinghausen's disease and vascular complications during pregnancy. J Gynecol Obstet Biol Reprod (Paris) 17:641645.

Humble RM. 1967. Phaeochromocytoma, neurofibromatosis and pregnancy. Anaesthesia 22:296-303.

Hyder SM, Stancel GM. 2002. Inhibition of progesterone-induced VEGF production in human breast cancer cells by the pure antiestrogen ICI 182,780. Cancer Lett 181:47-53.

Isikoglu M, Has R, Korkmaz D, Bebek N. 2002. Plexiform neurofibroma during and after pregnancy. Arch Gynecol Obstet 267:41-42

Jacobsen BM, Richer JK, Sartorius CA, Horwitz KB. 2003. Expression profiling of human breast cancers and gene regulation by progesterone receptors. J Mammary Gland Biol Neoplasia 8:257-268

Jacobsen BM, Schittone SA, Richer JK, Horwitz KB. 2005. Progesterone-independent effects of human progesterone receptors (PRs) in estrogen receptor-positive breast cancer: PR isoform-specific gene regulation and tumor biology. Mol Endocrinol 19:574-587.
Jarvis GJ, Crompton AC. 1978. Neurofibromatosis and pregnancy. Br J Obstet Gynaecol 85:844-846.

Karas RH. 2002. Animal models of the cardiovascular effects of exogenous hormones. Am J Cardiol 90:22F-25F.

Karvonen SL, Kallioinen M, Yla-Outinen $\mathrm{H}$, Poyhonen $\mathrm{M}$ Oikarinen A, Peltonen J. 2000. Occult neurofibroma and increased S100 protein in the skin of patients with neurofibromatosis type 1: New insight to the etiopathomechanism of neurofibromas. Arch Dermatol 136:1207-1209.

Klesse LJ, Parada LF. 1998. p21 ras and phosphatidylinositol-3 kinase are required for survival of wild-type and NF1 mutant sensory neurons. J Neurosci 18:10420-10428.

Klesse LJ, Meyers KA, Marshall CJ, Parada LF. 1999. Nerve growth factor induces survival and differentiation through two distinct signaling cascades in PC12 cells. Oncogene 18:2055-2068.

Klippel A, Reinhard C, Kavanaugh WM, Apell G, Escobedo MA Williams LT. 1996. Membrane localization of phosphatidylinositol 3-kinase is sufficient to activate multiple signaltransducing kinase pathways. Mol Cell Biol 16:4117-4127.

Kulik G, Klippel A, Weber MJ. 1997. Antiapoptotic signalling by the insulin-like growth factor I receptor, phosphatidylinositol 3-kinase, and Akt. Mol Cell Biol 17:1595-1606.

LaVallee TM, Zhan XH, Herbstritt CJ, Kough EC, Green SJ, Pribluda VS. 2002. 2-Methoxyestradiol inhibits proliferation and induces apoptosis independently of estrogen receptors alpha and beta. Cancer Res 62:3691-3697.

Lavigne MC, Ramwell PW, Clarke R. 1999. Inhibition of estrogen receptor function promotes porcine coronary artery smooth muscle cell proliferation. Steroids 64:472-480.

Lin HL, Liu TY, Wu CW, Chi CW. 2001. 2-Methoxyestradiolinduced caspase- 3 activation and apoptosis occurs through $\mathrm{G}(2) / \mathrm{M}$ arrest dependent and independent pathways in gastric carcinoma cells. Cancer 92:500-509.

Maran A, Zhang M, Kennedy AM, Sibonga JD, Rickard DJ, Spelsberg TC, Turner RT. 2002. 2-methoxyestradiol induces interferon gene expression and apoptosis in osteosarcoma cells. Bone 30:393-398.

McEwen BS, Alves SE. 1999. Estrogen actions in the central nervous system. Endocr Rev 20:279-307.

McLaughlin ME, Jacks T. 2003. Progesterone receptor expression in neurofibromas. Cancer Res 63:752-755.

Mize AL, Young LJ, Alper RH. 2003. Uncoupling of 5-HT1A receptors in the brain by estrogens: Regional variations in antagonism by ICI 182,780. Neuropharmacology 44:584-591.

Okada A, Sato T, Ohta Y, Iguchi T. 2005. Sex steroid hormone receptors in the developing female reproductive tract of laboratory rodents. J Toxicol Sci 30:75-89.

Packer RJ, Gutmann DH, Rubenstein A, Viskochil D, Zimmerman RA, Vezina G, Small J, Korf B. 2002. Plexiform neurofibromas in N F1:toward biologic-based therapy. Neurology 58:14611470.

Page PZ, Page GP, Ecosse E, Korf BR, Leplege A, Wolkenstein P. 2006. Impact of neurofibromatosis 1 on Quality of Life: A cross-sectional study of 176 American cases. Am J Med Genet Part A 140A:1893-1898.

Palmer C, Szudek J, Joe H, Riccardi VM, Friedman JM. 2004. Analysis of neurofibromatosis 1 (NF1) lesions by body segment. Am J Med Genet Part A 125A:157-161.

Parada LF, Kwon CH, Zhu Y. 2005. Modeling neurofibromatosis type 1 tumors in the mouse for therapeutic intervention. Cold Spring Harb Symp Quant Biol 70:173-176.

Parrizas M, LeRoith D. 1997. Insulin-like growth factor-1 inhibition of apoptosis is associated with increased expression of the bcl-xL gene product. Endocrinology 138:1355-1358.

Posma E, Aalbers R, Kurniawan YS, van Essen AJ, Peeters PM, van Loon AJ. 2003. Neurofibromatosis type I and pregnancy: A fatal attraction? Development of malignant schwannoma during pregnancy in a patient with neurofibromatosis type I. Bjog 110:530-532.

Puls LE, Chandler PA. 1991. Malignant schwannoma in pregnancy. Acta Obstet Gynecol Scand 70:243-244. 
Revankar CM, Cimino DF, Sklar LA, Arterburn JB, Prossnitz ER. 2005. A transmembrane intracellular estrogen receptor mediates rapid cell signaling. Science 307:1625-1630.

Ribella E. 1975. Su di un caso di gravidanza in donna affecta da neurofibromatosi. Minerva Ginecologica 27:607-613.

Robertson JA, Zhang Y, Ing NH. 2001. ICI 182,780 acts as a partial agonist and antagonist of estradiol effects in specific cells of the sheep uterus. J Steroid Biochem Mol Biol 77:281287

Rodriguez-Cuenca S, Gianotti M, Roca P, Proenza AM. 2006. Sex steroid receptor expression in different adipose depots is modified during midpregnancy. Mol Cell Endocrinol 249:5863.

Rodriguez-Viciana P, Warne PH, Vanhaesebroeck B, Waterfield MD, Downward J. 1996. Activation of phosphoinositide 3kinase by interaction with Ras and by point mutation. EMBO J $15: 2442-2451$

Roth TM, Ramamurthy P, Ebisu F, Lisak RP, Bealmear BM, Barald KF. 2007. A mouse embryonic stem cell model of Schwann cell differentiation for studies of the role of neurofibromatosis type 1 in Schwann cell development and tumor formation. Glia 55:1123-1133.

Roth TM, Ramamurthy P, Muir D, Wallace M, Zhu Y, Chang L, Barald KF. 2008. Influence of hormones and hormone metabolites on the growth of Schwann Cells derived from mouse embryonic stem cells and tumor cell lines expressing variable levels of neurofibromin. Dev Dyn 237:513-524.

Ruohola JK, Valve EM, Karkkainen MJ, Joukov V, Alitalo K, Harkonen PL. 1999. Vascular endothelial growth factors are differentially regulated by steroid hormones and antiestrogens in breast cancer cells. Mol Cell Endocrinol 149:29-40.

Schumacher G, Neuhaus P. 2001. The physiological estrogen metabolite 2-methoxyestradiol reduces tumor growth and induces apoptosis in human solid tumors. J Cancer Res Clin Oncol 127:405-410.

Sharma JB, Gulati N, Malik S. 1991. Maternal and perinatal complications in neurofibromatosis during pregnancy. Int J Gynecol Obstet 34:221-227.

Sibonga JD, Sommer U, Turner RT. 2002. Evidence that 2methoxyestradiol suppresses proliferation and accelerates apoptosis in normal rat growth plate chondrocytes. J Cancer Res Clin Oncol 128:477-483.

Sonneveld E, Riteco JA, Jansen HJ, Pieterse B, Brouwer A, Schoonen WG, van der Burg B. 2006. Comparison of in vitro and in vivo screening models for androgenic and estrogenic activities. Toxicol Sci 89:173-187.

Stokoe D, Stephens LR, Copeland T, Gaffney PR, Reese CB, Painter GF, Holmes AB, McCormick F, Hawkins PT. 1997. Dual role of phosphatidylinositol-3,4,5-trisphosphate in the activation of protein kinase B. Science 277:567-570.

Tapp E, Hickling RS. 1969. Renal artery rupture in a pregnant woman with neurofibromatosis. J Pathol 97:398-402.

Teoh H, Leung SW, Man RY. 1999. Short-term exposure to physiological levels of 17 beta-estradiol enhances endothelium-independent relaxation in porcine coronary artery. Cardiovasc Res 42:224-231.
Thomas SL, De Vries GH. 2007. Angiogenic expression profile of normal and neurofibromin-deficient human Schwann cells. Neurochem Res 32:1129-1141.

Tidwell C, Copas P. 1998. Brachial artery rupture complicating a pregnancy with neurofibromatosis: A case report. Am J Obstet Gynecol 179:832-834.

Tinley TL, Leal RM, Randall-Hlubek DA, Cessac JW, Wilkens LR, Rao PN, Mooberry SL. 2003. Novel 2-methoxyestradiol analogues with antitumor activity. Cancer Res 63:1538-1549.

Van Den Bemd GJ, Kuiper GG, Pols HA, Van Leeuwen JP. 1999. Distinct effects on the conformation of estrogen receptor alpha and beta by both the antiestrogens ICI 164,384 and ICI 182,780 leading to opposite effects on receptor stability. Biochem Biophys Res Commun 261:1-5.

Virdis R, Street M, Bandello M, Tripodi C, Donadio A, Villani A, Cagozzi L, Garavelli L, Bernasconi S. 2003. Growth and pubertal disorders in neurofibromatosis type 1. J Pediat Endocrinol Metab 16 (Supplement 2):289-292.

Viskochil D, White R, Cawthon R. 1993. The neurofibromatosis type 1 gene. Annu Rev Neurosci 16:183-205.

Wagner AH, Schroeter MR, Hecker M. 2001. 17beta-estradiol inhibition of NADPH oxidase expression in human endothelial cells. FASEB J 15:2121-2130.

Wakeling AE, Dukes M, Bowler J. 1991. A potent specific pure antiestrogen with clinical potential. Cancer Res 51:38673873.

Wang SH, Myc A, Koenig RJ, Bretz JD, Arscott PL, Baker JR. 2000. 2-Methoxyestradiol, an endogenous estrogen metabolite, induces thyroid cell apoptosis. Mol Cell Endocrinol 165: $163-172$.

Weissman A, Jakobi P, Zaidise I, Drugan A. 1993. Neurofibromatosis and pregnancy. An update. J Reprod Med 38: 890-896.

Wilson ME, Liu Y, Wise PM. 2002. Estradiol enhances Akt activation in cortical explant cultures following neuronal injury. Brain Res Mol Brain Res 102:48-54.

Witorsch RJ. 2002. Low-dose in utero effects of xenoestrogens in mice and their relevance to humans: An analytical review of the literature. Food Chem Toxicol 40:905-912.

Wiznitzer A, Katz M, Mazor M, Pinku A, Hagay ZJ. 1986. Neurofibromatosis in pregnancy. Four case reports and review of the literature. Isr J Med Sci 22:579-581.

Wolkenstein P, Zeller J, Revuz J, Ecosse E, Leplege A. 2001. Quality-of-life impairment in neurofibromatosis type 1: A cross-sectional study of 128 cases. Arch Dermatol 137:14211425.

Yao R, Cooper GM. 1995. Requirement for phosphatidylinositol-3 kinase in the prevention of apoptosis by nerve growth factor. Science 267:2003-2006.

Zhang Z, Cerghet M, Mullins C, Williamson M, Bessert D, Skoff R. 2004. Comparison of in vivo and in vitro subcellular localization of estrogen receptors alpha and beta in oligodendrocytes. J Neurochem 89:674-684.

Zhu Y, Ghosh P, Charnay P, Burns DK, Parada LF. 2002. Neurofibromas in N F1:Schwann cell origin and role of tumor environment. Science 296:920-922. 